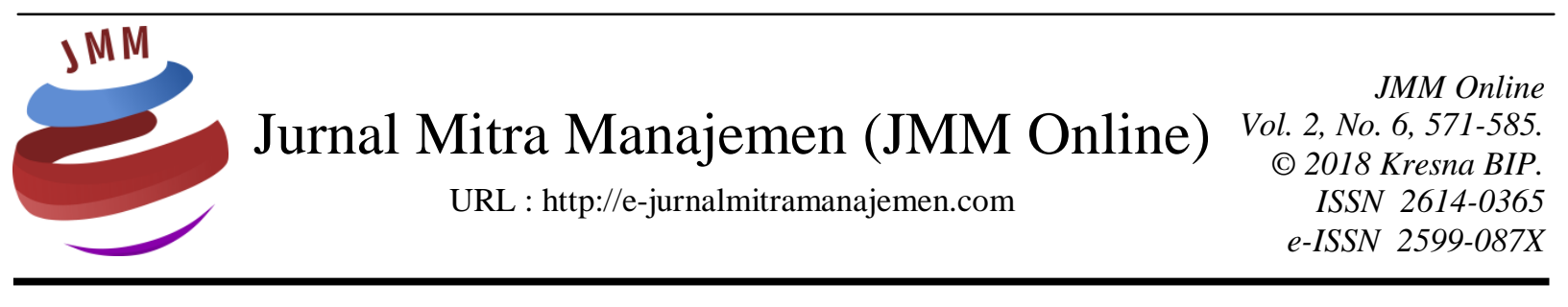

\title{
ANALISIS EFISIENSI DAN EFEKTIVITAS LAPORAN REALISASI ANGGARAN BELANJA LANGSUNG PADA UNIVERSITAS ISLAM NEGERI RADEN INTAN LAMPUNG
}

\author{
Dewita Sabrina \\ Institut Informatika dan Bisnis Darmajaya Bandar Lampung
}

INFORMASI ARTIKEL

Dikirim : 18 September 2018

Revisi pertama : 18 Oktober 2018

Diterima : 24 Oktober 2018

Tersedia online : 01 Desember 2018

Kata Kunci : Efisiensi, Efektivitas, Varians, Realisasi Anggaran Belanja Langsung

Email:dewitasabrina@gmail.com

\section{ABSTRAK}

Penelitian ini bertujuan untuk menganalisis tingkat efisiensi dan efektivitas realisasi anggaran belanja langsung berdasarkan standar kriteria menurut Kepmendagri No. 690.900.327 tahun 1996, serta menentukan kriteria nilai varians realisasi anggaran belanja langsung di Universitas Islam Negeri Raden Intan Lampung tahun 2013-2017. Metode yang digunakan adalah kuantitatif dengan pendekatan deskriptif. Data primer yaitu untuk memperoleh data yang sebenarnya; laporan realisasi anggaran belanja langsung tahun 20132017, dan data sekunder sebagai data pendukung. Hasil analisis menunjukkan penyerapan anggaran belanja langsung dengan kriteria tidak efisien, karena nilai persentase berada diatas standar kriteria efisien. Tetapi untuk tingkat efektivitas di tahun 2013-2017 telah memenuhi kriteria efektif. Sedangkan hasil analisis varians (selisih) antara anggaran belanja langsung dengan realisasinya tahun 2013-2017 memenuhi kriteria "baik". Sehingga secara keseluruhan dapat disimpulkan bahwa Universitas Islam Negeri Raden Intan Lampung telah efektif namun tidak efisien dalam realisasi anggaran belanja langsung selama 5 (lima) tahun. 


\section{PENDAHULUAN \\ Latar Belakang}

Pada dasarnya, anggaran merupakan pernyataan mengenai apa yang diharapkan dan direncanakan dalam periode tertentu di masa yang akan datang. Optimalisasi anggaran harus dilakukan secara ekonomis, efisien dan efektif (value for money) dalam rangka pertanggungjawaban publik (Kennis, (1979) dalam Danepo (2013)). Anggaran merupakan rincian biaya yang direncanakan sebelum kegiatan dilaksanakan, dan penggunaannya harus dapat dipertanggungjawabkan kepada stakeholder dengan membuat laporan hasil pembelanjaan dari anggaran tersebut (laporan realisasi anggaran belanja). Dengan laporan tersebut dapat diperoleh gambaran hasil kinerja keuangan di instansi terkait, secara efisien dan efektif, untuk dapat dievaluasi dan perbaikan di periode tahun berikutnya. Perkiraan keadaan yang akan terjadi di masa mendatang menjadi pertimbangan penting dalam penyusunan anggaran. Kemampuan melihat jauh ke depan akan menentukan ketepatan anggaran dengan realisasinya. Selisih (varians) antara anggaran dengan realisasinya menjadi indikator keberhasilan penyusunan anggaran. Sebagai konsekuensinya, penyusun cenderung selalu bersikap mencari aman dengan menetapkan anggaran pada angka yang relatif rendah dengan harapan agar dapat dengan mudah dicapai realisasinya. Selisih besaran antara realisasi dengan anggaran yang ditetapkan ini menjadi perhatian utama (Kuncoro, 2008).

Pengelolaan keuangan di Instansi/lembaga apabila tidak didukung oleh data dan laporan yang disesuaikan dengan kebutuhan, maka dalam pengambilan keputusan dapat mengakibatkan kesalahan, sehingga untuk menghabiskan dana anggaran maka aktivitas belanja menjadi menumpuk di akhir periode anggaran. Oleh sebab itu, berkaitan langsung dengan dana anggaran yang diperoleh dari stakeholder selaku pemberi dana anggaran, maka anggaran belanja serta realisasinya harus dioptimalkan oleh instansi/lembaga secara efisien dan efektif.

Instansi pemerintah yang berstatus Badan Layanan Umum (BLU), seperti yang terdapat dalam Undang-undang Nomor 1 Tahun 2004 pasal 68 dan pasal 69, Pasal 68 UU Perbendaharaan Negara menyebutkan bahwa pembentukan BLU dimaksudkan untuk meningkatkan pelayanan kepada masyarakat dalam rangka memajukan kesejahteraan umum dan mencerdaskan kehidupan bangsa dengan memberikan fleksibilitas dalam pengelolaan keuangan berdasarkan prinsip ekonomi dan produktivitas dan penerapan praktek bisnis yang sehat. Penerapan manajemen keuangan berbasis pada hasil atau kinerja di lingkungan instansi pemerintah seperti diatur dalam UU Perbendaharaan Negara membuka kemungkinan instansi pemerintah yang tugas pokok dan fungsinya memberi pelayanan kepada masyarakat untuk menerapkan pola pengelolaan keuangan yang fleksibel dengan menonjolkan produktivitas, efisiensi dan efektivitas melalui BLU. Peluang ini secara khusus disediakan kesempatannya bagi satuan-satuan kerja pemerintah yang secara fungsional melaksanakan tugas operasional pelayanan publik, seperti layanan kesehatan, pendidikan, pengelolaan kawasan, dan lisensi, untuk membedakannya dari fungsi pemerintah sebagai regulator dan penentu kebijakan. Instansi demikian, dengan sebutan umum sebagai Badan Layanan Umum (BLU), diharapkan menjadi contoh konkrit yang menonjol dari penerapan manajemen keuangan berbasis pada hasil (kinerja). 
Penelitian ini mengambil objek di salah satu instansi pemerintah sektor pelayanan dan jasa dibidang pendidikan tinggi negeri dibawah naungan kementerian agama yang telah berstatus Badan Layanan Umum (BLU) yaitu Universitas Islam Negeri Raden Intan Lampung, karena sebelum Institut Agama Islam Negeri Raden Intan Lampung menjadi Universitas Islam Negeri Raden Intan Lampung, telah ditetapkan melalui Keputusan Menteri Keuangan Nomor 277/KMK.05/2010 tentang penetapan Institut Agama Islam Negeri Raden Intan Lampung pada Departemen Agama sebagai Instansi Pemerintah yang menerapkan Pengelolaan Keuangan Badan Layanan Umum (PK-BLU). Sehingga pihak Universitas Islam Negeri Raden Intan Lampung perlu dan diwajibkan untuk menonjolkan produktivitas, efisiensi dan efektivitas dan mempertanggung-jawabkan aktivitas dari anggaran belanja kepada stakeholder (Pemerintah selaku pemberi dana anggaran). Dengan ini peneliti tertarik untuk menganalisis tingkat efisiensi dan efektivitas realisasi anggaran belanja khususnya pada belanja langsung (belanja pegawai, belanja barang/jasa, dan belanja modal), serta menganalisis nilai varians berdasarkan kriteria baik/tidak realisasi belanja langsung dari tahun ketahun yang keseluruhannya terdapat dalam laporan realisasi anggaran belanja di Universitas Islam Negeri Raden Intan Lampung dari tahun 20132017.

\section{Rumusan Masalah}

Berdasarkan latar belakang diatas, maka rumusan masalah pada penelitian ini adalah sebagai berikut:

1. Bagaimana tingkat efisiensi dalam laporan realisasi belanja langsung tahun 20132017 pada Universitas Islam Negeri Raden Intan Lampung?

2. Bagaimana tingkat efektivitas dalam laporan realisasi belanja langsung tahun 20132017 pada Universitas Islam Negeri Raden Intan Lampung?

3. Bagaimana kriteria nilai varians antara anggaran belanja langsung dengan realisasinya tahun 2013-2017 pada Universitas Islam Negeri Raden Intan Lampung?

\section{Tujuan Penelitian}

Berdasarkan rumusan masalah diatas, maka tujuan yang ingin dicapai dalam penelitian ini adalah sebagai berikut:

1. Menentukan tingkat efisiensi dalam laporan realisasi anggaran belanja langsung tahun 2013-2017 pada Universitas Islam Negeri Raden Intan Lampung berdasarkan Keputusan Menteri Dalam Negeri No. 690.900.327 tahun 1996.

2. Menentukan tingkat efektivitas dalam laporan realisasi anggaran belanja langsung tahun 2013-2017 pada Universitas Islam Negeri Raden Intan Lampung berdasarkan Keputusan Menteri Dalam Negeri No. 690.900.327 tahun 1996.

3. Menentukan kriteria pada nilai varians antara anggaran belanja langsung dengan realisasi anggaran belanja langsung tahun 2013-2017 pada Universitas Islam Negeri Raden Intan Lampung.

\section{KAJIAN PUSTAKA}

Teori anggaran menurut Lee, Jr. dan Johnson (1998) dalam penelitian Permana (2012); (terjemahan); Anggaran adalah dokumen atau kumpulan dokumen yang 
mengacu pada kondisi keuangan suatu organisasi, termasuk informasi tentang pendapatan, pengeluaran, aktivitas, dan tujuan atau sasaran, anggaran yang prospektif mengacu untuk mengantisipasi pendapatan, pengeluaran, dan prestasi masa depan.

Anggaran dapat diwujudkan dalam bentuk nyata yaitu dengan pelaksanaan anggaran (realisasi anggaran). Pengertian realisasi anggaran adalah seluruh kegiatan pelaksanaan anggaran yang juga meliputi kegiatan analisis serta evaluasi pelaksanaan budget (anggaran). Tujuan realisasi anggaran ini adalah untuk memberikan feedback serta follow up agar di periode-periode berikutnya bisa berjalan lebih baik lagi (Munandar: 2012). Realisasi merupakan langkah penting dalam suatu perencanaan terutama dalam sebuah anggaran belanja yang terkait langsung dengan kegiatan (belanja langsung). Kelompok belanja langsung berdasarkan Permendagri No. 21 Tahun 2011 terdiri dari belanja pegawai (honorarium/upah dalam melaksanakan program dan kegiatan), belanja barang/jasa (belanja barang pakai habis, bahan/material, jasa kantor, premi asuransi, perawatan kendaraan bermotor, cetak/penggandaan, sewa rumah/gedung/gudang/parkir, sewa sarana mobilitas, sewa alat berat, sewa perlengkapan dan peralatan kantor, makanan dan minuman, pakaian dinas dan atributnya, pakaian kerja, pakaian khusus dan hari-hari tertentu, perjalanan dinas, perjalanan dinas pindah tugas, dan pemulangan pegawai) dan belanja modal (mempunyai nilai manfaat lebih dari 12 (dua belas) bulan, seperti; tanah, peralatan dan mesin, gedung dan bangunan, jalan, irigasi dan jaringan dan aset tetap lainnya). Setelah anggaran direalisasikan, selanjutnya dibuat laporan untuk merangkum keseluruhan aktivitas belanja dari pelaksanaan anggaran (laporan realisasi anggaran belanja), kemudian dilakukan evaluasi atas hasil yang dicapai dengan menggunakan alat ukur yang tepat untuk menentukan sesuai atau tidak antara pencapaian dengan target yang telah ditentukan.

Beberapa ukuran ini dapat digunakan untuk hal tersebut, yaitu dengan mengukur serta menganalisis tingkat efisiensi (tingkat penghematan), mengukur tingkat efektivitas (pencapaian target dana anggaran yang diperoleh) berdasarkan kriteria standar efisiensi dan kriteria standar efektivitas menurut Keputusan Menteri Dalam Negeri No. 690.900.327 tahun 1996 tentang penilaian dan pencapaian kinerja keuangan dapat diketahui efisien atau tidak dan efektif atau tidak dengan memenuhi kriteria yang terdapat didalamnya. Mengukur baik/tidak nilai varians (selisih) antara realisasi dengan anggaran belanja langsung berdasarkan kriteria penilaian yang telah dijelaskan oleh Mahmudi (2010: 159). Apabila satuan kegiatan dan satuan uang telah menempati posisi penting atau segala kegiatan didalam anggaran dikuantifikasikan dalam satuan uang, maka dapat meningkatkan koordinasi dan komunikasi didalam anggaran.

\section{METODE PENELITIAN}

Penelitian ini merupakan jenis data kuantitatif dengan menggunakan pendekatan deskriptif. Objek dalam penelitian ini adalah Universitas Islam Negeri Raden Intan Lampung dan laporan realisasi anggaran belanja langsung sebagai subjek penelitian. Data kuantitatif ialah data yang diukur dalam skala numerik (angka) (Kuncoro, 2009:145), dengan menghitung tingkat efisiensi, efektivitas, menentukan kriteria berdasarkan nilai varians realisasi anggaran belanja langsung yang diperoleh 
dari laporan realisasi anggaran belanja di Universitas Islam Negeri Raden Intan Lampung tahun 2013-2017. Penelitian deskriptif adalah penelitian yang dilakukan untuk mengetahui keberadaan variabel mandiri, baik hanya pada satu variabel atau lebih tanpa membuat perbandingan atau menghubungkan dengan variabel lainnya (variabel mandiri adalah variabel yang berdiri sendiri, bukan variabel independen, karena kalau variabel independen selalu dipasangkan dengan variabel dependen (Sugiyono, 2015:53). Pendekatan deskriptif yang akan digunakan pada penelitian ini adalah dengan menganalisis/mendeskripsikan hasil dari perhitungan tingkat efisiensi, efektivitas, dan kriteria nilai varians realisasi anggaran belanja langsung dari tahun 2013-2017.

Penelitian ini dilakukan dari bulan Juni sampai bulan Agustus tahun 2018. Teknik pengumpulan data pada penelitian ini yaitu dengan studi dokumentasi. Dokumentasi adalah pengumpulan data dan dokumen-dokumen dan catatan yang berhubungan dengan masalah yang diteliti (Nugraini, 2012). Berikut analisis data yang digunakan:

1. Menghitung dan menentukan tingkat efisiensi realisasi anggaran belanja langsung, untuk mengukur tingkat penghematan anggaran dengan rumus; (Mahmudi, 2010:166).

\section{Realisasi Anggaran Belanja Langsung \\ Efisiensi = $\times 100 \%$}

Anggaran Belanja Langsung

Berdasarkan kriteria standar efisiensi menurut Keputusan Menteri Dalam Negeri No. 690.900.327 tahun 1996 tentang penilaian dan pencapaian kinerja keuangan dapat diketahui efisien atau tidak dengan memenuhi kriteria yaitu sebagai berikut:

Tabel 1. Kriteria Tingkat Efisiensi

\begin{tabular}{|c|c|}
\hline Persantase Tingkatan (\%) & Kriteria \\
\hline Di atas 100 & Tidak Efisien \\
\hline $90-100$ & Kurang Efisien \\
\hline $80-90$ & Cukup Efisien \\
\hline $60-80$ & Efisien \\
\hline Di bawah 60 & Sangat Efisien \\
\hline
\end{tabular}

Sumber: Depdagri, Kepmendagri No. 690.900.372 tahun 1996

Keterangan:

a) Jika hasil perbandingan lebih dari $100 \%$, maka anggaran belanja dikatakan tidak efisien

b) Jika hasil pencapaian antara 90\%-100\%, maka anggaran belanja dikatakan kurang efisien.

c) Jika hasil pencapaian antara $80 \%-90 \%$, maka anggaran belanja dikatakan cukup efisien.

d) Jika hasil pencapaian antara 60\%-80\%, maka anggaran belanja dikatakan efisien.

e) Jika hasil pencapaian dibawah $60 \%$, maka anggaran belanja dikatakan sangat efisien. 
2. Menghitung dan menentukan tingkat efektivitas yang diukur dengan cara membandingkan realisasi anggaran belanja langsung dengan target anggaran belanja langsung (Mardiasmo, 2009:132) adapun rumusnya yaitu :

$$
\text { Efektivitas }=\frac{\text { Realisasi Anggaran Belanja Langsung }}{\text { Target Anggaran Belanja Langsung }} \times 100 \%
$$

Berdasarkan standar efektivitas menurut Keputusan Menteri Dalam Negeri No. 690.900.327 tahun 1996 tentang penilaian dan pencapaian kinerja keuangan dapat diketahui efektif atau tidak dengan memenuhi kriteria yaitu sebagai berikut:

Tabel 2. Kriteria Tingkat Efektivitas

\begin{tabular}{|c|c|}
\hline Persantase Tingkatan (\%) & Kriteria \\
\hline Lebih dari 100 & Sangat Efektif \\
\hline $90-100$ & Efektif \\
\hline $80-90$ & Cukup Efektif \\
\hline $60-80$ & Kurang Efektif \\
\hline Di bawah 60 & Tidak Efektif \\
\hline
\end{tabular}

Keterangan:

Sumber: Depdagri, Kepmendagri No. 690.900.372 tahun 1996

a) Jika hasil perbandingan lebih dari $100 \%$, maka anggaran belanja dikatakan sangat efektif;

b) Jika hasil pencapaian antara 90\% - 100\%, maka anggaran belanja dikatakan efektif;

c) Jika hasil pencapaian antara $80 \%-90 \%$, maka anggaran belanja dikatakan cukup efektif;

d) Jika hasil pencapaian antara 60\% - 80\%, maka anggaran belanja dikatakan kurang efektif;

e) Jika hasil pencapaian dibawah 60\%, maka anggaran belanja dikatakan tidak efektif;

3. Analisis varians belanja langsung dirumuskan sebagai berikut (Mahmudi, 2010:157):

\section{Varians $=$ Realisasi Belanja - Anggaran Belanja}

Mengukur nilai varians belanja berdasarkan kriteria penilaian sebagai berikut:

Tabel 3. Kriteria Penilaian Varians Belanja

\begin{tabular}{|c|c|}
\hline Kriteria Varians Belanja & Ukuran \\
\hline Baik & Realisasi Belanja $\leq$ Anggaran Belanja \\
\hline Tidak Baik & Realisasi Belanja $\geq$ Anggaran Belanja \\
\hline
\end{tabular}

Sumber : Mahmudi (2010: 159).

Apabila terdapat selisih lebih (realisasi belanja langsung melebihi jumlah yang bersangkutan) maka dikatakan realisasi anggaran belanja langsung memiliki kriteria tidak baik, sedangkan jika terdapat selisih kurang (realisasi belanja langsung kurang dari jumlah yang dianggarkan) maka pengelolaan keuangan belanja langsung dapat dinilai baik. 
HASIL PENELITIAN DAN PEMBAHASAN

Hasil Penelitian

Analisis Efisiensi

Tabel 4. Perhitungan Tingkat Efisiensi Tahun 2013-2017

\begin{tabular}{|c|c|c|c|c|c|c|}
\hline Tahun & $\begin{array}{c}\text { Anggaran Belanja } \\
\text { Langsung }\end{array}$ & $\begin{array}{c}\text { Realisasi Belanja } \\
\text { Langsung }\end{array}$ & Perhitungan & Tingkat Efisiensi & Ukuran & Kriteria \\
\hline 2013 & 66.466 .446 .000 & 60.713 .916 .973 & $\frac{60.713 .916 .973}{66.466 .446 .000} \times 100 \%$ & $91 \%$ & $\leq 80 \%$ & Kurang Efisien \\
\hline 2014 & 57.301 .498 .000 & 52.497 .063 .268 & $\frac{52.497 .063 .268}{57.301 .498 .000} \times 100 \%$ & $92 \%$ & $\leq 80 \%$ & Kurang Efisien \\
\hline 2015 & 105.024 .122 .000 & 95.409 .772 .580 & $\frac{95.409 .772 .580}{105.024 .122 .000} \times 100 \%$ & $91 \%$ & $\leq 80 \%$ & Kurang Efisien \\
\hline 2016 & 129.495 .215 .000 & 123.181 .467 .910 & $\frac{123.181 .467 .910}{129.495 .215 .000} \times 100 \%$ & $95 \%$ & $\leq 80 \%$ & Kurang Efisien \\
\hline 2017 & 101.301 .814 .000 & 91.285 .816 .344 & $\frac{91.285 .816 .344}{101.301 .814 .000} \times 100 \%$ & $90 \%$ & $\leq 80 \%$ & Kurang Efisien \\
\hline \multicolumn{7}{|c|}{ Rata-Rata } \\
\hline
\end{tabular}

Sumber: Hasil Penelitian, diolah (2018)

Berdasarkan pada tabel diatas, dapat diketahui bahwa tahun 2013 menunjukkan tingkat efisiensi sebesar 91\% atau dalam kriteria kurang efisien $(\leq 80 \%)$, di tahun 2014 jumlah persentasenya meningkat menjadi sebesar $92 \%$ dengan kriteria kurang efisien $(\leq 80 \%)$, tahun 2015 jumlahnya persentasenya kembali menjadi $91 \%$ atau masih dalam kriteria kurang efisien $(\leq 80 \%)$. Kemudian di tahun 2016 jumlah persentasenya kembali meningkat yaitu sebesar 95\% dengan kriteria kurang efisien $(\leq 80 \%)$, Sedangkan di tahun 2017 jumlah persentasenya sebesar 90\%, jumlah persentase ini juga menurun dibandingkan dengan tahun sebelumnya yaitu tahun 2016, tahun 2015, tahun 2014, dan tahun 2013. Berikut ini merupakan tingkat efisiensi anggaran belanja langsung di Universitas Islam Negeri Raden Intan Lampung yang dapat digambarkan dalam bentuk grafik, yaitu;

Gambar 1. Grafik Efisiensi Belanja Langsung

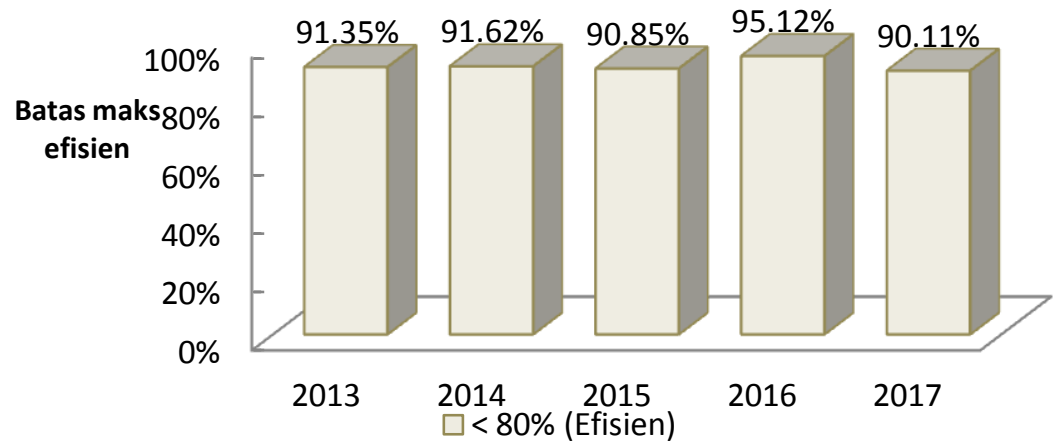

Sumber: Hasil Penelitian, Diolah (2018)

Grafik efisiensi belanja langsung pada gambar diatas menunjukkan adanya pergerakan tingkat efisiensi yang stabil di Universitas Islam Negeri Raden Intan Lampung dalam merealisasikan anggaran belanja langsung dan menggambarkan bahwa tingkat efisiensi dari tahun 2013 sampai tahun 2017 tingkat efisiensi belanja 
langsung dengan nilai rata-rata mencapai $92 \%$ atau dapat dinilai kurang efisien, sebab nilai presentase tidak memenuhi kriteria efisien yaitu $\leq 80 \%$.

\section{Analisis Efektivitas}

Tabel 5. Perhitungan Tingkat Efektivitas Tahun 2013-2017

\begin{tabular}{|c|c|c|c|c|c|c|}
\hline Tahun & $\begin{array}{c}\text { Target Anggaran } \\
\text { Belanja Langsung }\end{array}$ & $\begin{array}{c}\text { Realisasi Anggaran } \\
\text { Belanja Langsung }\end{array}$ & \multicolumn{1}{c|}{ Perhitungan } & $\begin{array}{c}\text { Tingkat } \\
\text { Efektivitas }\end{array}$ & Ukuran & Kriteria \\
\hline 2013 & 63.784 .418 .000 & 66.466 .446 .000 & $\frac{66.466 .446 .000}{63.784 .418 .000} \times 100 \%$ & $104 \%$ & $\geq 90 \%$ & Efektif \\
\hline 2014 & 54.346 .470 .000 & 57.301 .498 .000 & $\frac{57.301 .498 .000}{54.346 .470 .000} \times 100 \%$ & $105 \%$ & $\geq 90 \%$ & Efektif \\
\hline 2015 & 93.089 .968 .000 & 105.024 .122 .000 & $\frac{105.024 .122 .000}{93.089 .968 .000} \times 100 \%$ & $113 \%$ & $\geq 90 \%$ & Efektif \\
\hline 2016 & 117.415 .801 .000 & 129.495 .215 .000 & $\frac{129.495 .215 .000}{117.415 .801 .000} \times 100 \%$ & $110 \%$ & $\geq 90 \%$ & Efektif \\
\hline 2017 & 108.923 .466 .000 & 101.301 .814 .000 & $\frac{101.301 .814 .000}{108.923 .466 .000} \times 100 \%$ & $93 \%$ & $\geq 90 \%$ & Efektif \\
\cline { 3 - 7 } & & & $\underline{\text { Rata-rata }}$ & $\mathbf{1 0 5 \%}$ & $\geq \mathbf{9 0 \%}$ & Efektif \\
\hline
\end{tabular}

Sumber: Hasil Penelitian, diolah (2018)

Berdasarkan hasil perhitungan pada tabel diatas, menunjukkan bahwa target anggaran belanja langsung dan anggaran belanja langsung yang diperoleh hasil persentase tahun 2013 mencapai 104\%, dengan kriteria efektif ( $\geq 90 \%)$. Tahun 2014 terjadi peningkatan mencapai $105 \%$, dengan kriteria efektif ( $\geq 90 \%)$. Kemudian tahun 2015 juga mengalami peningkatan yaitu sebesar $113 \%$, dengan kriteria efektif $(\geq 90 \%)$. Selanjutnya ditahun 2016 menurun menjadi sebesar 110\%, dengan kriteria efektif $(\geq 90 \%)$. Dan ditahun 2017 hanya sebesar 93\%, namun masih dalam kriteria efektif, karena hasil persentase tersebut telah mencapai kriteria tingkat efektivitas yaitu $\geq 90 \%$, hal ini dikarenakan selisih antara target anggaran yang lebih besar daripada anggaran yang diperoleh, yaitu sebesar Rp. 7.621.652.000,-. Namun dari keseluruhan, hasil yang dicapai oleh Universitas Islam Negeri Raden Intan Lampung dalam mewujudkan target anggaran belanja langsung yang terealisasi atau tingkat efektivitas realisasi anggaran belanja langsung telah mencapai kriteria efektif yaitu $\geq 90 \%$, dengan nilai persentase rata-rata tingkat efektivitas mencapai $105 \%$ selama 5 (lima) tahun. Berikut ini merupakan tingkat efektivitas anggaran belanja langsung di Universitas Islam Negeri Raden Intan Lampung yang dapat digambarkan dalam bentuk grafik, yaitu;

\section{Gambar 2. Grafik Efektivitas Belanja Langsung}

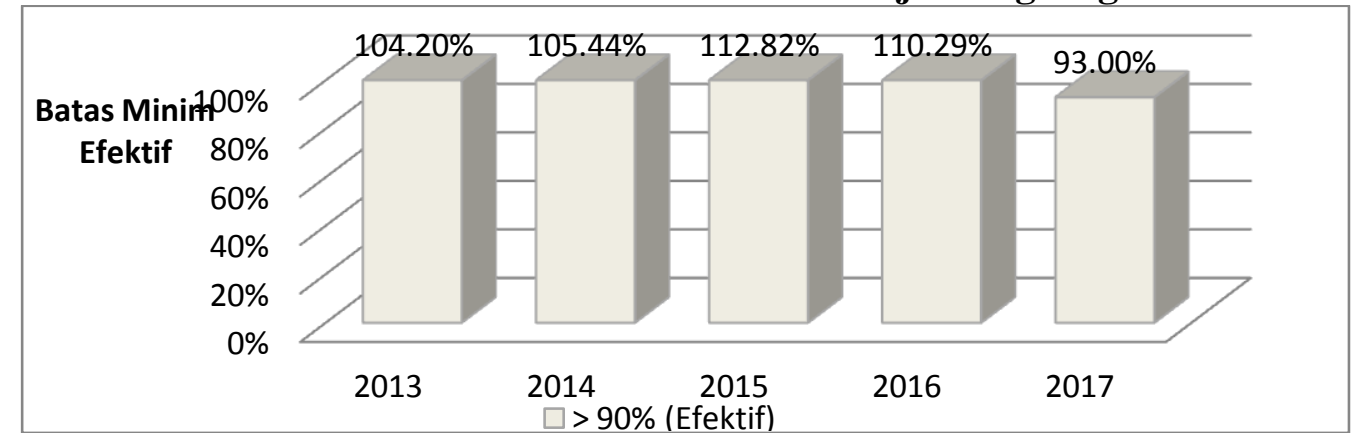

Sumber: Hasil Penelitian, diolah (2018) 
Grafik diatas menggambarkan pergerakan efektivitas belanja langsung di Universitas Islam Negeri Raden Intan Lampung, terlihat bahwa tahun 2013-2017 mengalami tingkat efektivitas yang stabil, dan secara keseluruhan tingkat efektivitas dapat dinilai efektif, sebab persentase rata-rata tingkat efektivitas mencapai $105 \%$ selama 5 (lima) tahun atau $\geq 90 \%$.

\section{Analisis Varians}

Tabel 6. Perhitungan Varians Belanja Langsung

\begin{tabular}{|c|c|c|c|c|c|c|}
\hline \multirow{2}{*}{ Tahun } & \multicolumn{2}{|c|}{ Varians $=\mathbf{a}-\mathbf{b}$} & \multirow{2}{*}{ Selisih } & \multirow{2}{*}{ Persentase } & \multirow{2}{*}{ Ukuran } & \multirow{2}{*}{$\begin{array}{c}\text { Nilai } \\
\text { Varians } \\
\end{array}$} \\
\hline & Realisasi (a) & Anggaran (b) & & & & \\
\hline 2013 & 60.713 .916 .973 & 66.466 .446 .000 & -5.752 .529 .027 & $-8,7 \%$ & $a<b$ & Baik \\
\hline 2014 & 52.497 .063 .268 & 57.301 .498 .000 & -4.804 .434 .732 & $-8,4 \%$ & $a<b$ & Baik \\
\hline 2015 & 95.409 .772 .580 & 105.024 .122 .000 & -9.614 .349 .420 & $-9,2 \%$ & $a<b$ & Baik \\
\hline 2016 & 123.181.467.910 & 129.495 .215 .000 & -6.313 .747 .090 & $-4,9 \%$ & $a<b$ & Baik \\
\hline 2017 & 91.285 .816 .344 & 101.301 .814 .000 & -10.015 .997 .656 & $-9,9 \%$ & $\mathrm{a}<\mathrm{b}$ & Baik \\
\hline \multicolumn{3}{|c|}{ Rata-rata } & -7.300 .211 .585 & $-8,2 \%$ & $\mathbf{a}<\mathbf{b}$ & Baik \\
\hline
\end{tabular}

Sumber: Hasil Penelitian, diolah (2018)

Berdasarkan tabel diatas menunjukkan bahwa nilai varians (selisih) anggaran belanja langsung dengan realisasi anggaran belanja langsung di Universitas Islam Negeri Raden Intan Lampung tahun 2013-2017 secara keseluruhan dapat dinilai baik dalam penyerapan belanja langsung. Pernyataan tersebut dapat dijelaskan dari hasil perhitungan diatas yang menunjukkan bahwa anggaran belanja langsung tahun 2013 sebesar Rp 66.466.446.000,- dan realisasi belanja langsung sebesar Rp 60.713.916.973,- atau 91\%, sehingga menimbulkan selisih sebesar Rp 5.752.529.027 atau $8,7 \%$ yang tidak terealisasi dari total anggaran yang diterima. Anggaran belanja langsung tahun 2014 sebesar Rp 57.301.498.000,- dan realisasi belanja langsung sebesar Rp 52.497.063.268,- atau 93\%, sehingga menimbulkan selisih sebesar Rp 4.804.434.732,- atau 8,4\% yang tidak terealisasi dari total anggaran yang diterima. Anggaran belanja langsung tahun 2015 sebesar Rp 105.024.122.000,- dan realisasi belanja langsung sebesar Rp 95.409.772.580,- atau 91\%, sehingga menimbulkan selisih sebesar $\mathrm{Rp}$ 9.614.349.420,- atau 9,2\% yang tidak terealisasi dari total anggaran yang diterima. Kemudian anggaran belanja langsung tahun 2016 sebesar Rp. 129.495.215.000,- dan realisasi belanja langsung sebesar Rp. 123.181.467.910,- atau 95\%, sehingga menimbulkan selisih sebesar Rp. 6.313.747.090,- atau 4,9\% yang tidak terealisasi dari total anggaran yang diterima. Sedangkan tahun 2017 menunjukkan anggaran belanja langsung sebesar Rp 101.301.814.000,- dan realisasi belanja langsung sebesar Rp 94.989.098.992,- atau 90\% sehingga selisih belanja menjadi sebesar Rp 10.015.997.656,- atau 9,9\% yang tidak terealisasi dari total anggaran yang diterima. Berikut gambar grafik varians; 
Gambar 3. Grafik Varians Belanja Langsung

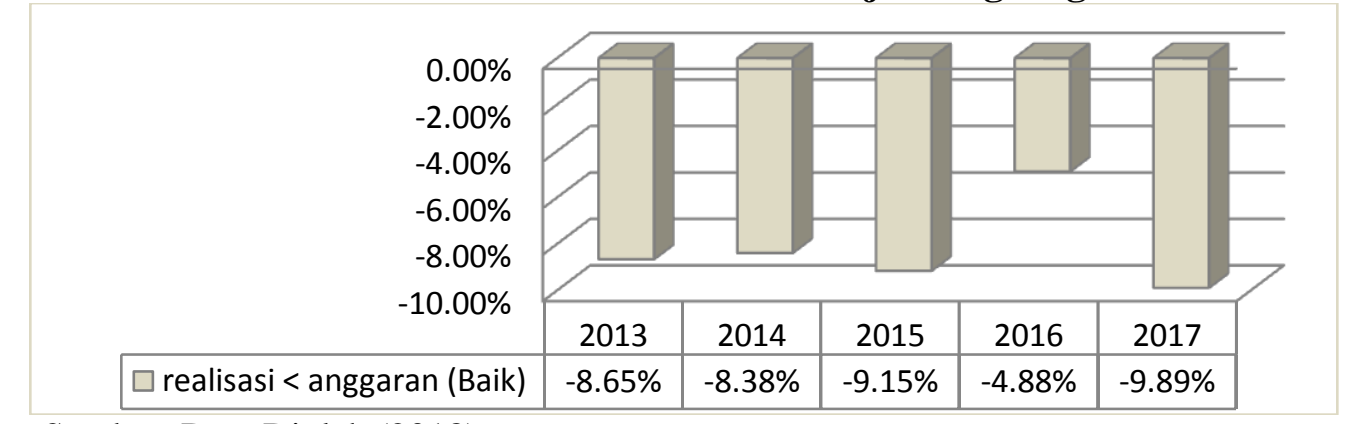

Sumber: Data Diolah (2018)

Grafik diatas menggambarkan nilai varians belanja langsung di Universitas Islam Negeri Raden Intan Lampung, terlihat bahwa dari tahun 2013-2017 menunjukkan adanya selisih antara realisasi dengan anggaran belanja langsung, ditahun 2017 mengalami selisih yang paling banyak dari tahun-tahun sebelumnya atau dapat dikatakan bahwa anggaran belanja langsung tidak terealisasi dengan baik.

\section{Pembahasan}

\section{Analisis Efisiensi}

Menilai tingkat efisiensi realisasi anggaran belanja langsung yang terdapat di Universitas Islam Negeri Raden Intan Lampung pada penelitian ini diukur berdasarkan standar kriteria efisiensi menurut Keputusan Menteri Dalam Negeri No. 690.900.327 tahun 1996. Apabila kriteria penilaian $\leq 80 \%$ maka realisasi anggaran belanja langsung telah efisien dan sebaliknya jika $\geq 80 \%$ maka realisasi anggaran belanja langsung tidak efisien. Hal itu mendukung pendapat Saron (2017) yang menyatakan bahwa semakin kecil angka persentase maka semakin efisien pelaksanaan anggaran belanja begitu pula sebaliknya, semakin besar angka persentase maka semakin tidak efisien pelaksanaan anggaran belanja. Kriteria efisiensi merupakan bagian yang paling penting dalam pengukuran realisasi anggaran belanja karena penggunaan belanja akan terlihat pada tingkatan ini, dengan adanya kriteria tersebut juga dapat diketahui cara organisasi/instansi dalam memanfaatkan anggarannya sesuai dengan program/kegiatan yang direncanakan dengan menekan biaya yang serendah-rendahnya, atau memaksimalkan tujuan dengan meminimalkan biaya yang dikeluarkan.

Berdasarkan hasil perhitungan dan diukur dengan standar kriteria efisiensi, maka dapat dinyatakan bahwa pencapaian realisasi anggaran belanja langsung di Universitas Islam Negeri Raden Intan Lampung dari tahun 2013-2017 secara keseluruhan berada dalam kriteria kurang efisien sebab nilai persentase rata-rata sebesar $92 \%$, namun telah berusaha melakukan peningkatan efisiensi dalam mengelola anggarannya, yang dibuktikan dengan tingkat efisiensi tahun 2017 berada pada kriteria kurang efisien, namun telah mendekati standar kriteria efisiensi yaitu 80\%. Realisasi anggaran belanja langsung yang kurang efisien menandakan bahwa dalam mengelola kebutuhan belanja langsung tidak menggunakan anggaran yang diperlukan dengan menekan biaya seminimal mungkin untuk memperoleh hasil yang optimal. Pernyataan ini mendukung pendapat Santoso (2011) yang menyatakan bahwa suatu kegiatan dikatakan efisien jika pelaksaan pekerjaan tersebut telah mencapai hasil dengan biaya 
yang terendah atau dengan biaya minimal diperoleh hasil yang diinginkan, didalam penelitiannya menunjukkan hasil rata-rata tingkat efisiensi masih rendah, hal itu menunjukkan bahwa pemerintah daerah yang menjadi objek penelitiannya masih boros dalam menggunakan anggarannya. Sama halnya dengan pernyataan yang telah diberikan oleh Trianto (2014) dalam penelitiannya, yaitu suatu kegiatan dikatakan efisien apabila mencapai hasil yang baik dengan pengorbanan (biaya) biaya yang sedikit, dan didalam penelitiannya diperoleh hasil bahwa tingkat efisiensi keuangan pada pemerintah daerah yang ditelitinya selama periode 2003-2013 rata-rata berada pada tingkat kurang efisien dan tidak efisien, bahkan pada periode tahun 2009 dan 2013 rasio efisiensi telah melebihi dari angka 80\% yang menandakan belanja daerah yang diteliti telah melebihi anggaran yang tersedia sehingga pengeluaran belanja tersebut dibiayai dengan pinjaman/hutang.

\section{Analisis Efektivitas}

Efektivitas (hasil guna) adalah ukuran keberhasilan suatu organisasi dalam usaha mencapai tujuan organisasi yang telah ditetapkan. Semakin tinggi tingkat efektivitas sebuah anggaran, maka semakin tinggi tingkat keberhasilan sebuah organisasi/instansi dalam menjalankan program/kegiatan yang telah ditentukan. Tingkat efektivitas dalam pengelolaan keuangan dapat dilihat berdasarkan realisasi anggaran belanja langsung dengan target anggaran belanja langsung. Hal ini mendukung pendapat Saron (2017) yang menyatakan bahwa Semakin besar realisasi angggaran maka akan semakin tinggi pula persentase tingkat efektifitas pelaksanaan anggaran.

Berdasarkan hasil perhitungan dan diukur dengan standar kriteria efektivitas menurut Keputusan Menteri Dalam Negeri No. 690.900.327 tahun 1996, menunjukan bahwa tingkat efektivitas pada anggaran belanja langsung di Universitas Islam Negeri Raden Intan Lampung terlihat bahwa seluruhnya telah masuk dalam kriteria efektif, karena memiliki tingkat efektivitas rata-rata $\geq 90 \%$ (efektif), hal ini menunjukkan bahwa dalam menentukan target penerimaan anggaran telah sesuai, dan mampu merealisasikan anggaran yang telah direncanakan dibandingkan dengan target yang ditetapkan berdasarkan potensinya, hal ini dibuktikan dengan perolehan anggaran yang lebih besar daripada anggaran awal yang direncanakan. Sedangkan pada tahun 2017 dinilai belum dapat mewujudkan realisasi anggaran belanja langsung dengan optimal dan sesuai target, melainkan target yang hendak dicapai masih belum tercapai dengan baik atau realisasi anggaran yang diperoleh lebih rendah daripada anggaran yang direncanakan. Namun secara keseluruhan telah masuk pada kriteria efektif.

Tercapainya tingkat efektivitas dengan kriteria efektif menggambarkan bahwa Universitas Islam Negeri Raden Intan Lampung telah berhasil menjalankan tugas dengan semestinya, yang dilihat berdasarkan pencapaian target anggaran belanja langsung yang teralisasi. Pernyataan ini mendukung pendapat Santoso (2011) yang menyatakan bahwa efektivitas lebih menitik beratkan pada tingkat keberhasilan organisasi dalam mencapai tujuan yang telah ditetapkan, didalam penelitiannya menunjukkan pola perkembangan tingkat efektivitas pengelolaan keuangan daerah yang diteliti dari tahun 2005-2010 cenderung stabil dengan rata-rata sebesar 94,03\% pertahun, dengan demikian berarti tingkat efektivitasnya sudah efektif sebab $\geq 90 \%$. 
Sama halnya dengan penelitian yang telah dilakukan Trianto (2014) yang menunjukkan bahwa secara keseluruhan, rata-rata nilai rasio efektivitas keuangan daerah yang diteliti periode tahun 2003-2013 mencapai tingkat yang efektif. Hal ini berarti pemerintah daerah yang diteliti telah berhasil dalam merealisasikan Pendapatan Asli Daerah dari target yang diperkirakan sebelumnya sehingga potensi Pendapatan Asli Daerah yang ada dapat dimaksimalkan oleh pemerintah daerah untuk menunjang pembangunan di daerah tersebut.

\section{Analisis Varians}

Anggaran belanja merupakan batas maksimal pengeluaran yang boleh dilakukan instansi pemerintah. Dalam hal ini instansi pemerintah akan dinilai baik dalam penyerapan anggaran belanjanya apabila realisasi belanja tidak melebihi dari yang dianggarkan, sebaliknya jika realisasi belanja lebih besar dari jumlah yang dianggarkan maka hal itu mengindikasikan adanya penyerapan anggaran belanja yang kurang baik (Budiman, dan Wokas, 2015). Analisis varians merupakan analisis terhadap perbedaan atau selisih antara realisasi belanja dengan anggaran belanja. Analisis varians cukup sederhana namun dapat memberikan informasi yang sangat berarti. Berdasarkan laporan realisasi anggaran yang disajikan, pengguna laporan dapat mengetahui secara langsung besarnya varian anggaran belanja dengan realisasinya yang bisa dinyatakan dalam bentuk nilai nominalnya atau presentasenya (Mahmudi, 2010:156).

Berdasarkan kriteria penilaian yang telah dijelaskan oleh Mahmudi (2010:159), analisis varians yang diperoleh dari hasil perhitungan yang menyatakan bahwa penyerapan anggaran belanja langsung di Universitas Islam Negeri Raden Intan Lampung selama tahun anggaran 2013-2017 dinilai baik. Sebab realisasi belanja langsung tidak melebihi anggarannya. Jumlah anggaran yang tidak ter-realisasi bisa dilihat dari persentase dan nominalnya yang cukup besar. Dalam melakukan analisis varians anggaran, hendaknya memperhatikan penghematan yang dilakukan berdasarkan angka presentasi, tetapi juga jumlah nominalnya. Semakin sedikit sisa anggaran belanja maka pencapaian dalam penyerapan anggaran belanja di sebuah instansi menjadi semakin baik, namun dalam penyerapannya tidak melebihi dana anggaran yang diperoleh. Dan sebaliknya jika sisa anggaran banyak yang tidak terrealisasi maka pencapaian dalam penyerapan di instansi tersebut menjadi kurang baik karena rencana kerja yang dilakukan dan realisasinya kurang maksimal.

Nilai varians atas realisasi dengan anggaran belanja langsung di Universitas Islam Negeri Raden Intan Lampung secara keseluruhan menunjukkan nilai varians dengan perolehan nilai rata-rata sebesar $8,2 \%$ selisih anggaran belanja langsung yang tidak terealisasi selama 5 (tahun), atau 92\% anggaran belanja langsung yang terealisasi selama 5 (lima) tahun. Namun penilaian varians belanja ini melihat baik atau tidak baik dalam pengelolaan keuangan yang dalam hal ini adalah anggaran belanja langsung. Dengan melihat apakah realisasi belanja langsung $\leq$ anggaran belanja langsung atau bahkan sebaliknya. Penelitian ini mendukung penelitian terdahulu yang telah dilakukan oleh Julita (2015) yang menganalisis kenerja pendapatan dan kinerja belanja di instansi daerah yang ditelitinya berdasarkan analisis varians secara umum dapat dikatakan sudah baik. maka pengelolaan keuangannya dapat dinilai baik. 


\section{KESIMPULAN DAN SARAN Kesimpulan}

Berdasarkan hasil pembahasan atau analisis terhadap data penelitian yang telah dilakukan, dan diukur menggunakan standar kriteria efisiensi menurut Keputusan Menteri Dalam Negeri No. 690.900.327 tahun 1996, maka diketahui bahwa pencapaian realisasi anggaran belanja langsung di Universitas Islam Negeri Raden Intan Lampung dari tahun 2013-2017 secara keseluruhan berada dalam kriteria kurang efisien sebab nilai persentase rata-rata sebesar $92 \%$. Hal ini menandakan bahwa dalam mengelola kebutuhan belanja langsung tidak menggunakan anggaran yang diperlukan dengan menekan biaya seminimal mungkin untuk memperoleh hasil yang optimal.

Perkembangan tingkat efektivitas anggaran belanja langsung di Universitas Islam Negeri Raden Intan Lampung tahun 2013-2017 yang diukur menggunakan standar kriteria efektivitas menurut Keputusan Menteri Dalam Negeri No. 690.900.327 tahun 1996 telah dilakukan dan hasilnya menunjukkan bahwa hasil pencapaian realisasi anggaran yang diperoleh rata-rata mencapai $105 \%$ jika disesuaikan dengan standar efektivitas Kepmendagri maka nilai tersebut sudah berada pada kategori sangat efektif.

Sedangkan hasil analisis varians (selisih) anggaran belanja langsung dengan realisasinya di Universitas Islam Negeri Raden Intan Lampung selama tahun anggaran 2013-2017 telah mencapai kriteria "baik", Sebab realisasi belanja langsung tidak melebihi anggarannya, terlihat pada jumlah selisih yang menjelaskan bahwa realisasi belanja langsung $\leq$ anggaran belanja langsung. Jumlah anggaran yang tidak terealisasi bisa dilihat dari persentase dan nominalnya yang cukup besar. Varians belanja yang baik yakni realisasi belanja tidak melebihi anggaran yang ditetapkan serta penyerapan anggaran jangan terlalu rendah akan tetapi tidak melebihi anggaran yang sudah ditetapkan sebelumnya. Sebab penyerapan anggaran belanja yang rendah bisa mengindikasikan adanya kelemahan dalam perencanaan anggaran yang akan dilaksanakan. Semakin sedikit sisa anggaran maka pencapaian dalam penyerapan anggaran belanja langsung di instansi semakin baik. Sebaliknya jika sisa anggaran banyak maka pencapaian dalam penyerapan suatu instansi kurang baik karena rencana kerja yang dilakukan kurang maksimal. Berdasarkan kriteria penilaian varians tersebut, maka dapat disimpulkan bahwa secara keseluruhan nilai varians realisasi anggaran belanja langsung $\leq$ anggaran belanja langsung, atau dengan kriteria "Baik".

\section{Saran}

Berdasarkan hasil analisis dan kesimpulan yang telah diuraikan, maka dapat diberikan saran sebagai berikut :

1) Bagi Universitas Islam Negeri Raden Intan Lampung;

Perlu meningkatkan efisiensi dan efektivitas dalam pengelolaan anggaran belanja langsung ditahun-tahun selanjutnya, agar pencapaian program dan kegiatan baik pada belanja pegawai, belanja barang/jasa, maupun belanja modal (dalam kelompok belanja langsung) dari tahun ketahun sesuai dengan yang diharapkan dan dapat mencapai tujuan secara optimal, tidak mengalami pemborosan, atau terlalu menghemat anggaran. Anggaran belanja langsung dapat terserap dengan baik, 
secara efektif dan efisien, agar pergerakan pertumbuhan realisasi anggaran belanja langsung dapat meningkat ditahun-tahun selanjutnya.

2) Bagi Peneliti Selanjutnya;

Apabila ada peneliti lain yang tertarik mengadakan penelitian yang hampir sama, sebaiknya meneliti tentang anggaran belanja langsung dan anggaran belanja tidak langsung secara lebih mendalam dan lebih rinci (misalnya anggaran belanja pertriwulan dalam satu periode anggaran atau dalam beberapa periode anggaran), serta dapat meneliti tentang proses jalannya program kegiatan anggaran belanja langsung yang dilakukan, sesuai dengan peraturan yang sudah ditetapkan oleh Pemerintah. Selain menggunakan analisis efisiensi, efektivitas, dan varians yang dijadikan sebagai patokan dalam penelitian ini, peneliti menyarankan untuk menambah alat analisis lain seperti analisis ekonomi, aktivitas, analisis kemandirian, analisis keserasian belanja dan lain-lain sebagai pendukung dari analisis diatas, kemudian dapat menggunakan ukuran lain untuk menganalisis dan menentukan hasil penelitiannya.

\section{DAFTAR PUSTAKA}

Budiman, Rizal Y. Wokas, Heince. 2015. Analisis Kinerja Belanja dalam Laporan Realisasi Anggaran pada Tiga Daerah Pemekaran di Provinsi Sulawesi Utara.

Danepo, Muhammad. 2013. Pengaruh Partisipasi dalam Penganggaran dan Peran Manajemen Publik Pengelola Keuangan Daerah Terhadap Kinerja Pemerintah Daerah dengan Objek Penelitian pada SKPD Pemerintah Kabupaten/Kota seProvinsi Lampung.

Depdagri. 1997. Kepmendagri No.690.900.327, 1996, Tentang Pedoman Penilaian dan Kinerja Keuangan.

Julita, S. M. 2015. Analisis Efektivitas dan Efisiensi Anggaran Pendapatan dan Belanja pada BLH Provinsi Sumatera Utara. Jurnal Universitas Muhammadiyah Sumatera Utara Vol.10 No. 02 Tahun 2011.

Kuncoro, Haryo. 2008. Variansi Anggaran dan Realisasi Anggaran Belanja Studi Kasus Pemerintah Daerah Provinsi DKI Jakarta. Jurnal Manajemen Teori dan Terapan Vol. 1 No. 2 Tahun 2008

Kuncoro, Mudrajad. 2009. Metode Riset Untuk Bisnis \& Ekonomi. Jakarta: Penerbit Erlangga.

Mahmudi. 2010. Manajemen Kinerja Sektor Publik. Edisi Revisi. Yogyakarta: UPP STIM YKPN.

Mardiasmo. 2009. Akuntansi Sektor Publik. Yogyakarta: Andi.

Munandar. 2012. Budgeting: Perencanaan Kerja, Pengkoordinasian Kerja dan Pengawasan Kerja. Edisi kedua. Yogyakarta: Penerbit Bpfe.

Nugraini, Esty Muchina. 2012. Analisis Rasio Keuangn Anggaran Pendapapatan dan Belanja Daerah (APBD) dalam Menilai Kinerja Keuangan Pemerintah Daerah Kabupaten Jember. Skripsi. Universitas Jember.

Pemerintah Republik Indonesia. 2011. Peraturan Menteri Dalam Negeri No. 21. Tentang Klasifikasi Belanja. Jakarta.

Peraturan Menteri Agama Republik Indonesia Nomor 35 Tahun 2014. Tentang Status Institut Agama Islam Negeri Raden Intan Lampung 
Permana, Ryan. 2012. Analisis Implementasi Penganggaran Berbasis Kinerja Studi Kasus pada Universitas Indonesia. Depok.

Santoso, Eko. 2011. Efisiensi dan Efektivitas Pengelolaan Keuangan Daerah di Kabupaten Ngawi. Tesis.

Saron, Yusra. 2017. Analisa Efektifitas dan Efisiensi Pelaksanaan Anggaran Belanja Kantor Kesatuan Bangsa dan Politik (KESBANGPOL) Kabupaten Tanah Datar. Padang.

Sugiyono. 2015. Metode Penelitian Kuantitatif Kualitatif $R \& B$. Bandung: Aflabeta.

Trianto, Anton. 2014. Analisis Efektivitas dan Efisiensi Pengelolaa Keuangan Daerah di Kota Palembang. Jurnal Akuisisi.

Undang-Undang No. 1 tahun 2004 tentang Perbendaharaan Negara. 